\title{
A novel mechanism of HIV transcytosis and infection
}

\author{
S Gupta*, JC Becerra, DN Forthal \\ From AIDS Vaccine 2012 \\ Boston, MA, USA. 9-12 September 2012
}

\section{Background}

Female genital tract mucosae are bathed in acidic secretions, which, in the case of HIV-1 infected women, likely contain virus coated with antibody. Thus, uninfected male sexual partners are often exposed to an acidic milieu containing virus in the form of immune complexes. We investigated the impact of low $\mathrm{pH}$ and antibody on transcytosis, a potentially critical mechanism by which HIV-1 passes through genital tract epithelia to infect susceptible target cells.

\section{Methods}

HIV-1 was incubated with Env-specific monoclonal and polyclonal antibodies at $\mathrm{pH} 6.0$ or $\mathrm{pH} 7.4$ and exposed to the apical surface of tight junction-forming human endometrial carcinoma (HEC-1) cells in transwell plates. The quantity and infectivity of transcytosed virus was measured by RT-PCR and infection of TZMbl cells, respectively.

\section{Results}

We found that the combination of acidic pH and Env-specific antibody augmented transcytosis as much as 30 -fold compared with Env-specific antibody at neutral pH or compared with non-specific antibody or no antibody at neutral or acidic $\mathrm{pH}$. The $\mathrm{pH}$ and antibody dependence of enhanced transcytosis was blocked by antibody specific for the Fc neonatal receptor (FcRn) or by treatment with bafilomycin A1 (which inhibits acidification of endosomes). Non-neutralizing antibodies resulted in a lower quantity of total transcytosed virus, measured by RT-PCR, than did neutralizing antibodies. However, the ratio of total to infectious virus was much higher for neutralizing antibodies, indicating that neutralizing antibodies efficiently allow transcytosis while blocking infectivity of the

University of California Irvine, Irvine, CA, USA transcytosed virus; the non-neutralizing antibodies facilitate transcytosis (although to a lesser degree than the neutralizing antibodies) without blocking infectivity.

\section{Conclusion}

These results demonstrate that acidity and Env-specific antibody greatly enhance transcytosis of virus across mucosal epithelial cells via FcRn. Since male penile and urethral tissues express FcRn, our results suggest a novel mechanism by which antibody, and in particular, nonneutralizing antibody, might facilitate female-to-male transmission following sexual exposure.

Published: 13 September 2012

doi:10.1186/1742-4690-9-S2-P206

Cite this article as: Gupta et al:: A novel mechanism of HIV transcytosis and infection. Retrovirology 2012 9(Suppl 2):P206.
Submit your next manuscript to BioMed Central and take full advantage of:

- Convenient online submission

- Thorough peer review

- No space constraints or color figure charges

- Immediate publication on acceptance

- Inclusion in PubMed, CAS, Scopus and Google Scholar

- Research which is freely available for redistribution
() Bïomed Central
(C) 2012 Gupta et al; licensee BioMed Central Ltd. This is an Open Access article distributed under the terms of the Creative Commons Attribution License (http://creativecommons.org/licenses/by/2.0), which permits unrestricted use, distribution, and reproduction in any medium, provided the original work is properly cited. 